\title{
USE OF NIR SPECTROSCOPY AND 3D PRINCIPAL COMPONENT ANALYSIS FOR PARTICLE SIZE CONTROL OF DRIED MEDICINAL PLANTS
}

\section{UPOTREBA BLISKE INFRACRVENE SPEKTROSKOPIJE I 3D ANALIZE GLAVNIH KOMPONENTI ZA KONTROLU VELIČINE ČESTICA SUŠENOG LEKOVITOG BILJA}

\author{
Davor VALINGER ${ }^{*}$, Maja BENKOVIĆ*, Tamara JURINA*, Ana JURINJAK TUŠEK*, \\ Ana BEL $\check{S} \check{C} A K-C V I T A N O V I C^{* *}$, Jasenka GAJDOŠ KLJUSURIĆ ${ }^{*}$ Ingrid BAUMAN* \\ * University of Zagreb, Department of Process Engineering, Faculty of Food Technology and Biotechnology, Croatia \\ ** University of Zagreb, Department of Food Engineering, Faculty of Food Technology and Biotechnology, Croatia \\ e-mail: mbenkovic@pbf.hr
}

\begin{abstract}
The regular or in-line measurement of particle size is an essential requirement for quality control throughout food industry to ensure a consistent product output. Non-invasive spectroscopy in the near infrared range from 904 - $1699 \mathrm{~nm}$ (NIR) was applied to investigate the possibility of differentiation of five different medicinal plants (chamomile, dandelion, nettle, broadleaf plantain and yarrow). Dry plants were milled and after sieving four fractions were obtained with following particle sizes: $<100 \mu \mathrm{m}, 100-280 \mu \mathrm{m}$, 280-450 $\mu \mathrm{m}$ and $>450 \mu \mathrm{m}$. Raw spectra and first derivative of raw spectra were recorded and principle component analysis (PCA) of first three factors was applied (3D PCA). 3D PCA showed better differentiation for first derivative compared to the raw spectra for all five medicinal plants and all analyzed particle sizes. Particle size fractions were photographed using microscope in order to explain analysis results for fractions $280-450 \mu \mathrm{m}$ and $>450 \mu \mathrm{m}$, where the presence of smaller particles was visible for all five medicinal plants.
\end{abstract}

Key words: near infrared spectroscopy, principle component analysis, particle size, medicinal plants.

\section{REZIME}

Redovno ili linijsko merenje veličine čestica je ključni uslov za kontrolu kvaliteta u prehrambenoj industriji kako bi se osigurao konzistentan proizvod. Jedna od nedestruktivnih i najbržih analitičkih tehnika koja pruža uvid u hemijska i fizička svojstva ispitivanih materijala je bliska infracrvena spektroskopija. Neinvazivna spektroskopija u bliskom infracrvenom opsegu od 904 - $1699 \mathrm{~nm}$ (NIR) je primenjena da se ispita mogućnost diferencijacije pet različitih lekovitih biljaka (kamilica, maslačak, kopriva, stolisnik i trputac). Osušene biljke su samlevene i prosejane na odgovarajućem slogu sita pri čemu su dobijene 4 frakcije čestica sledećih veličina: $<100 \mu \mathrm{m}, 100-280 \mu \mathrm{m}, 280-450 \mu \mathrm{m} i>450 \mu \mathrm{m}$. Dobijene frakcije su snimane NIR instrumentom bez prethodnog tretmana. Na snimljene spektre i njihove prve derivacije primenjena je analiza glavnih komponenta (PCA) za prva tri faktora (3D PCA) korišćenjem programskih paketa StatSoft Statistica v.10 $i$ Wolfram Research Mathematica v.10. 3D PCA je pokazala bolju diferencijaciju za prve derivacije nego za početne spektre za svih pet lekovitih biljaka i za sve analizirane veličine čestica. Različite frakcije čestica su fotografisane pomoću mikroskopa (Bresser LCD-35) kako bi objasnili rezultate analize za frakcije 280-450 $\mu$ m i > 450 um, gde je bilo vidljivo prisustvo manjih čestica za svih pet lekovitih biljaka.

Ključne reči: bliska infracrvena spektroskopija, analiza glavnih komponenata, veličina čestica, lekovito bilje.

\section{INTRODUCTION}

A significant number of literature reports have emerged over the past 20-30 years regarding the use of near infrared spectroscopy (NIRS) as both a research tool for formulation development and as a quality control technology for monitoring unit operations for product manufacturing (Ely et al., 2008). The demand for consistent and improved quality of food products requires development of instrumental methods for rapid determination of quality parameters. Currently, a great deal of interest is focused on the application of spectroscopic techniques such as nearinfrared (NIR) that enable non-destructive at-/online monitoring in the food and pharmaceutical industries. NIR spectroscopy measures molecular vibrations that, in contrast to midinfrared (MIR) radiation, can be transmitted through quartzbased optical fibers, enabling simple and flexible sampling on the process line. Previous studies have shown that NIR spectroscopy has great potential as an analytical technique for the determination of homogeneity of powder blends (Scotter, 1990; Wargo and Drennen, 1996; Muzzio, Robinson, Wightman and Brone, 1997; Luner, Majuru, Seyer and Kemper, 2000; ElHagrasy, Morris, D’Amico, Lodder and Drennen, 2003) and quantification of lactose content (Kaffa, Norris, Kulscár and Draskovits, 1982; Baer, Frank, Loewenstein and Birth, 1983; Buckton, Yonemochi, Hammond and Moffat, 1998; Laporte and Paquin, 1999; Lane and Buckton, 2000; Tarkosova and 
Copikova, 2000; Hogan and Buckton, 2001) in various food systems. NIR spectrum provides characteristic information on the internal constituents of the sample, so it has been widely used in dispensation, such as component analysis of Chinese herbal plants Angelicae gigantis radix (Woo et al., 2005), rhubarb (Zhang and Tang, 2005), licorice (Wang et al., 2007), Panax species (Chen et al., 2011), and Lonicera japonica (Wu et al., 2012), as well as a content detection of active pharmaceutical ingredients (APIs) in tablets (Paris et al., 2006; Jamrógiewicz, 2012 and Porfire et al., 2012).

It is well known that NIR spectra contains both chemical and physical information (such as particle size and bulk density) (Barnes et al., 1989; Papini, 1996; Pasikatan et al., 2001). This technique has enabled the development of non-invasive on-line monitoring methods that provide analytical results allowing running processes to be corrected if needed, the time used in each step shortened and quality in the end-product increased (Alcalà et al., 2010).

In the present work, differences in particle size fractions of five medicinal plants: chamomile (Matricaria recutita L.), dandelion (Taraxacum officinale L.) nettle (Urtica dioica L.), broadleaf plantain (Plantago major L.) and yarrow (Achillea millefolium L.) have been monitored using NIR spectroscopy. NIR spectrometer (Control Development, Inc., USA) has been used for the on-line spectral acquiring as a non-invasive approach. Principal component analysis for the first three components (3D PCA) and microscopic imaging (Bresser, Germany) have been used for monitoring and distinguishing different particle size fractions of five medicinal plants.

\section{MATERIAL AND METHOD}

Plant material

Dried plant materials of chamomile (flower), dandelion (leaves), nettle (leaf), broadleaf plantain (leaf) and yarrow (flower + leaves) were purchased from a specialized herbal store (Suban d.o.o., Strmec, Croatia). All plant materials were collected in the north-western part of Croatia during the flowering season of 2015 for each plant, dried and properly stored until used.

\section{Milling}

Dried plant material was milled using IKA Tube mill control (IKA-Werke, Staufen, Germany). Milling conditions were adjusted as follows: $20000 \mathrm{~min}^{-1}$ for 40 seconds. Since the plant material had different organic structures and thus different hardness, for some samples milling time was reduced to 20 seconds. After milling, samples were kept in a desiccator until further used.

\section{Separation of particle size fractions}

Milled plant material was subjected to sieving in order to separate the particle size fractions. The following sieves were used: 100, 280 and $450 \mu \mathrm{m}$ pore opening. Four different particle size fractions were obtained marked as $<100 \mu \mathrm{m}, 100-280 \mu \mathrm{m}$, $280-450 \mu \mathrm{m}$ and $>450 \mu \mathrm{m}$, which were then subjected to NIR analysis.

\section{NIR analysis}

The NIR spectra (range extends from $904 \mathrm{~nm}$ to $1699 \mathrm{~nm}$ ) of medicinal plants for different particle sizes were collected with the setup for NIRS studies that included: a laptop, NIR-128-1.7$\mathrm{USB} / 6.25 / 50 \mu \mathrm{m}$ scanning monochromator from Control
Development, Inc., provided with Spec32 software, the polychromatic source of light, optical cables, and a hemispherical cup that serves as a sample tray. The two cables serve to provide incident light and to collect the light reflected by the product being tested. Complete NIR instrument setup has been previously described in detail by Valinger et al., (2011). In the NIRS studies, ten consecutive runs for every particle size of each medicinal plant were initially recorded across the entire spectral range. Also, the first derivative of the entire spectral range was recorded using Savitsky-Golay first derivative (degree 2). No mechanical or chemical treatment of the samples was needed prior to NIRS measurements.

\section{Principal Component Analysis in 3D}

PCA identifies the spectral variations generated from each sample and reduces the number of dimensions in experimental data in order to identify the spectral features of greatest importance. Data are re-projected along the axes of greatest variation, called principal components (PC). A score (factor) is calculated along each principal component axis for each sample that is a linear combination of feature intensities weighted by relative importance in the model. Because the score is related to spectral features, materials with similar compositions will plot close to one another in PCA scores space. Data obtain by NIRS were used to perform principal component analysis (PCA) by means of statistical software StatSoft STATISTICA v. 10 (StatSoft Inc., USA) and were plotted in 3D using Wolfram Research Mathematica v.10 (Wolfram Research, USA). Since program Statistica is limited in plotting just 2 factors, Mathematica was used to plot three factors in three dimensions (3D PCA) for better distinguishing between different particle size fractions.

\section{Microscopic imaging}

Light microscope imaging was performed on the milled plant material samples in order to identify size, structure and type of particles present in the samples. Samples were viewed by a BTC Type LCD-35 (Bresser, Rhede, Germany) microscope at 4x magnification and photographed by an integrated microscope camera.

\section{RESULTS AND DISCUSSION}

Using NIR instrument 10 recordings were made for every particle size fraction $(<100 \mu \mathrm{m}, 100-280 \mu \mathrm{m}, 280-450 \mu \mathrm{m}$ and $>450 \mu \mathrm{m}$ ) and for each plant (chamomile, dandelion, nettle, broadleaf plantain and yarrow) resulting in 200 recordings of pre-processed (raw) spectra and also 200 first derivatives of raw spectra. Example of 10 raw spectra for nettle samples for particle size of $<100 \mu \mathrm{m}$ are presented in Fig. 1A while the first derivative of the raw spectra in Fig.1B. Although the Fig. 1B seems like one spectrum, all 10 spectra are presented in this figure. This is because derivatives of spectral data are used to remove or suppress constant background signals and to enhance visual resolution. Background signals and global base-line variations are low-frequency phenomena, so derivatives can be interpreted as high-pass filters (Siesler et al., 2002).

The application of cluster analysis (PCA) for the raw data of the five medicinal plants in the plane of first three principal components are presented in Fig. 2. 
For the particle sizes less than $100 \mu \mathrm{m}$, very good differentiation between five medicinal plants can be observed (Fig. 2A) which is not the case for other particle sizes (Fig. 2B, 2C, 2D). The first component (factor) extracted in a principal component analysis accounts for a maximal amount of total variance in the observed variables. The second component extracted will have two important characteristics. First, this component will account for a maximal amount of variance in the data set that was not accounted for by the first component.

The remaining components that are extracted in the analysis display the same two characteristics: each component accounts for a maximal amount of variance in the observed variables that was not accounted for by the preceding components, and is uncorrelated with all of the preceding components (Sisler et al., 2002). For the explanation of what each component represents in term of chemical or physical information (particle size, color, water concentration ...) an appropriate data library is required. Libraries of spectra that are representative of the natural variation in each product to be identified later can be built up during the calibration process.

Better differentiation between five medicinal plants using PCA was obtained for all of the different particle sizes using first derivatives of raw spectra (Fig. 3).

In order to identify size, structure and type of particles present in the samples, light microscope imaging was performed on investigated medicinal plant samples

Due to restriction of space, only nettle images for all four different particle size fractions are presented in Fig. 4.

Images for particle sizes less than $100 \mu \mathrm{m}$ and 100-280 $\mu \mathrm{m}$ (Fig. 4A and B) show uniformed particle size distribution while for the fraction 280-450 $\mu \mathrm{m}$ (Fig. 4C) and fraction $>450$ $\mu \mathrm{m}$ (Fig. 4D), smaller particles can be noticed (Fig. 4D). The same trend in particle size distribution was observed for all medicinal plants (data not shown). Based on microscopic images, it can be concluded that the presence of smaller particles in fractions $280-450$ and $>450 \mu \mathrm{m}$, causes difficulties in distinguishing of samples using PCA analysis. This also indicates that if the particle sizes were all uniformed, PCA analysis would show better cluster separation (this can be observed especially for Fig. 3D).
A)

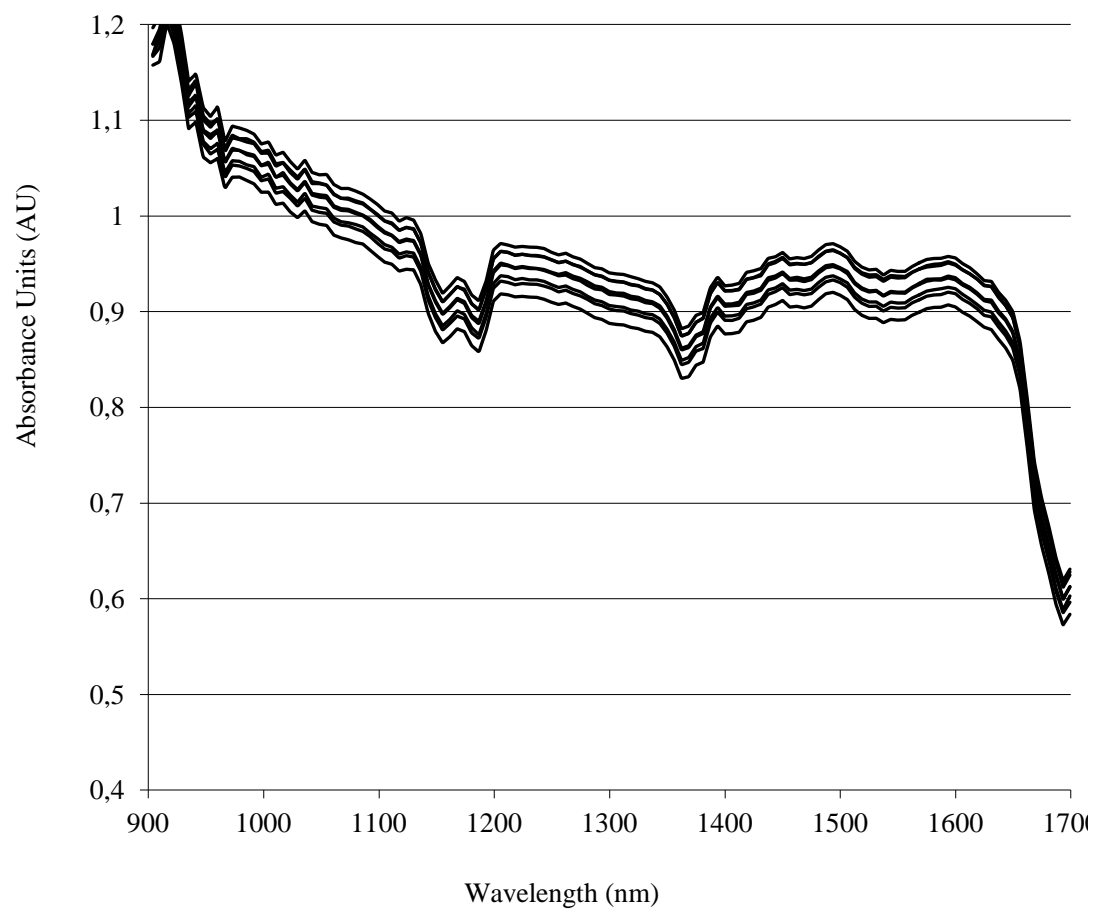

B)

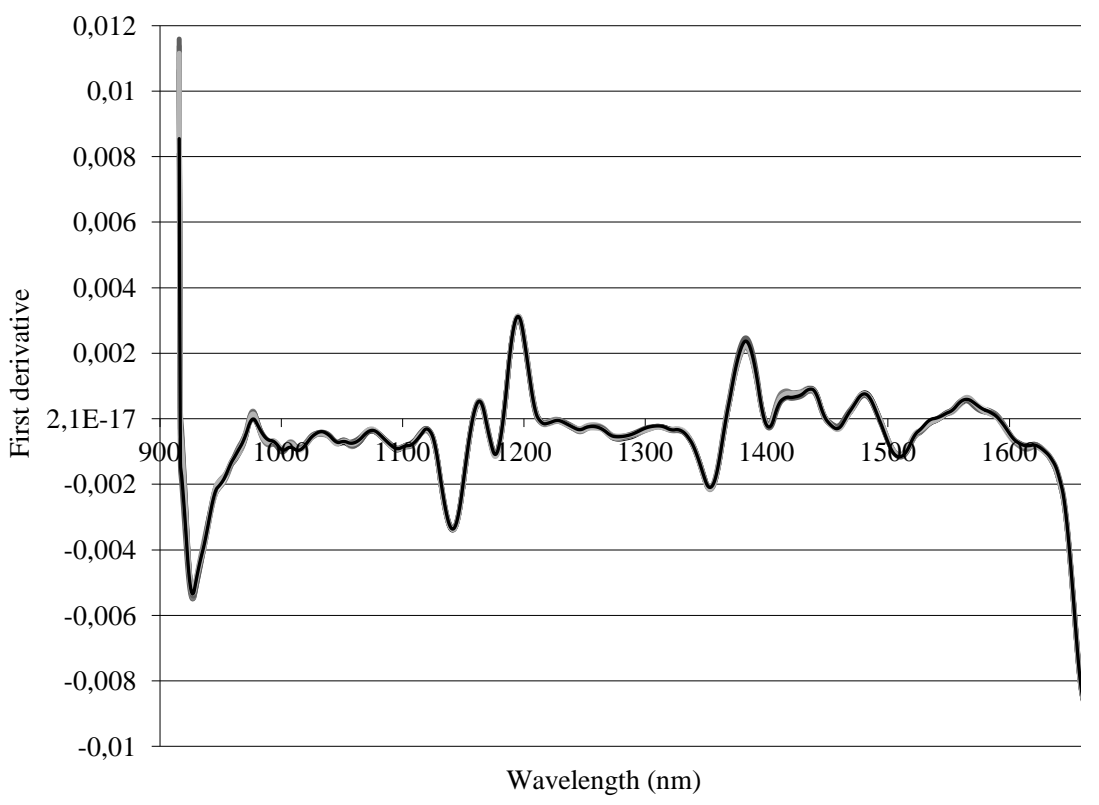

Fig. 1. Sample of NIR spectra corresponding to the raw data A) and first derivates $B$ ) for $<100 \mu \mathrm{m}$ particle size fraction of nettle 
A)

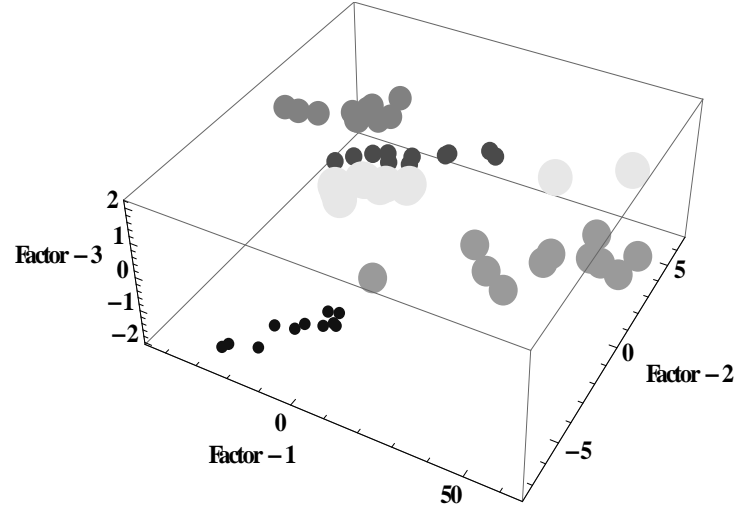

B)

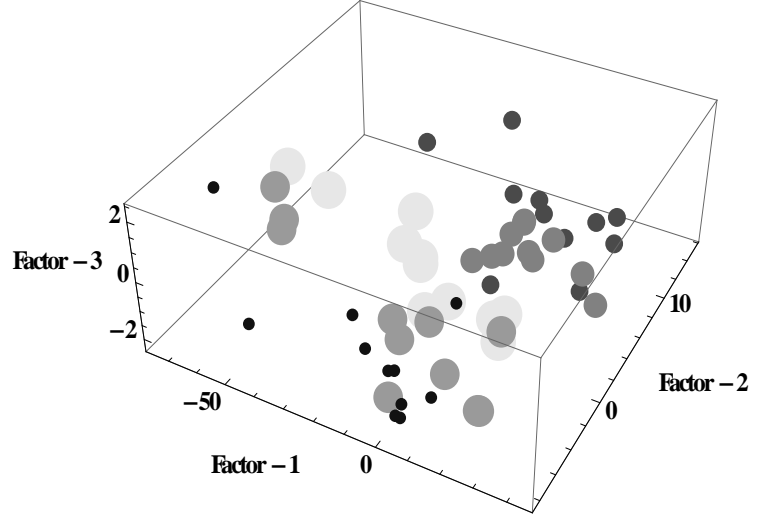

C)

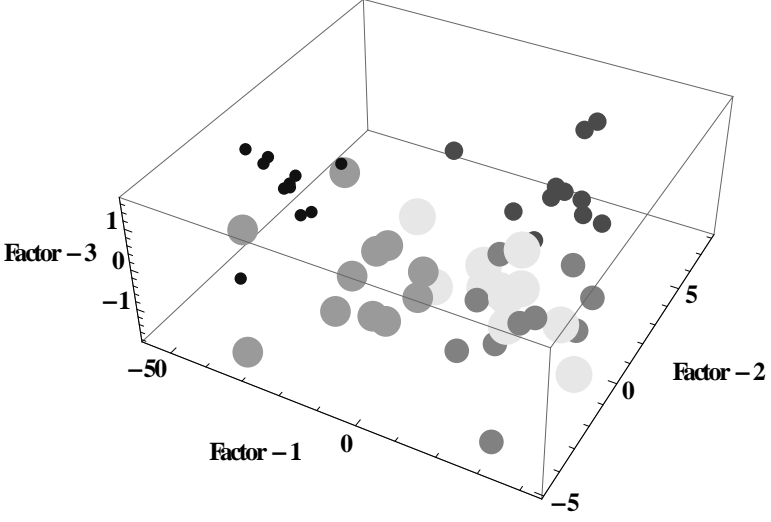

D)

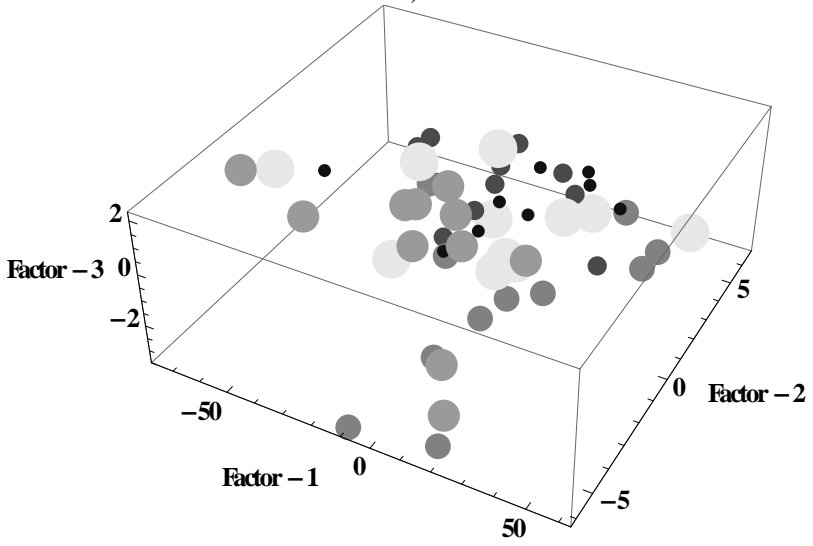

Fig. 2. Principal Component Analysis of raw spectra presented by first three factors for particle size fractions A) $<100 \mu \mathrm{m} \mathrm{B)}$ $100-280 \mu \mathrm{m}$ C) $280-450 \mu \mathrm{m}$ and $\mathrm{D}$ ) $>450 \mu \mathrm{m}$ ( chamomile samples, onettle samples, Odandelion samples, yarrow samples and broadleaf plantain samples)
A)

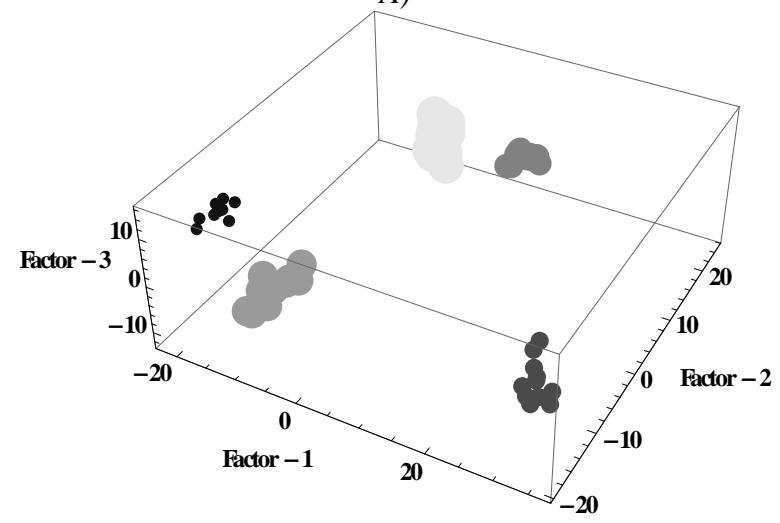

B)

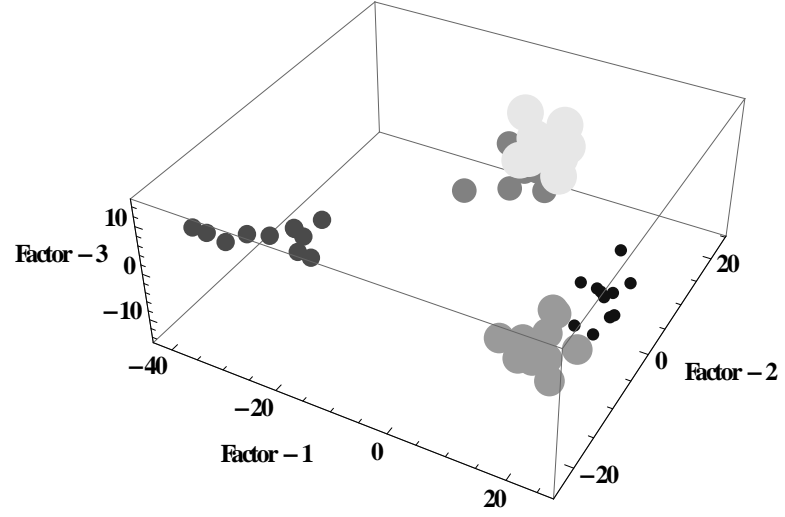

C)

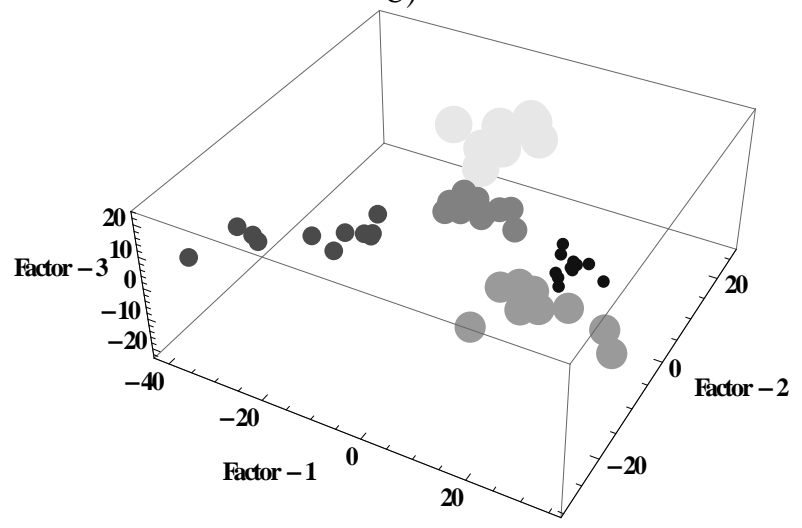

D)

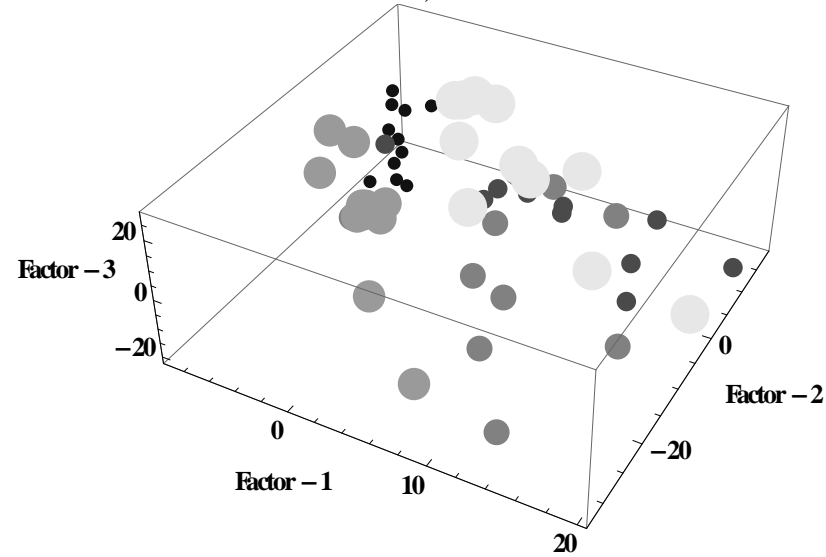

Figure 3. Principal Component Analysis of first derivatives spectra presented by first three factors for particle size fractions A) $<100 \mu \mathrm{m} \mathrm{B)} 100-280 \mu \mathrm{m}$ C) $280-450 \mu \mathrm{m}$ and D) $>450 \mu \mathrm{m}$ (•chamomile samples, - nettle samples, edandelion samples, yarrow samples and broadleaf plantain samples) 

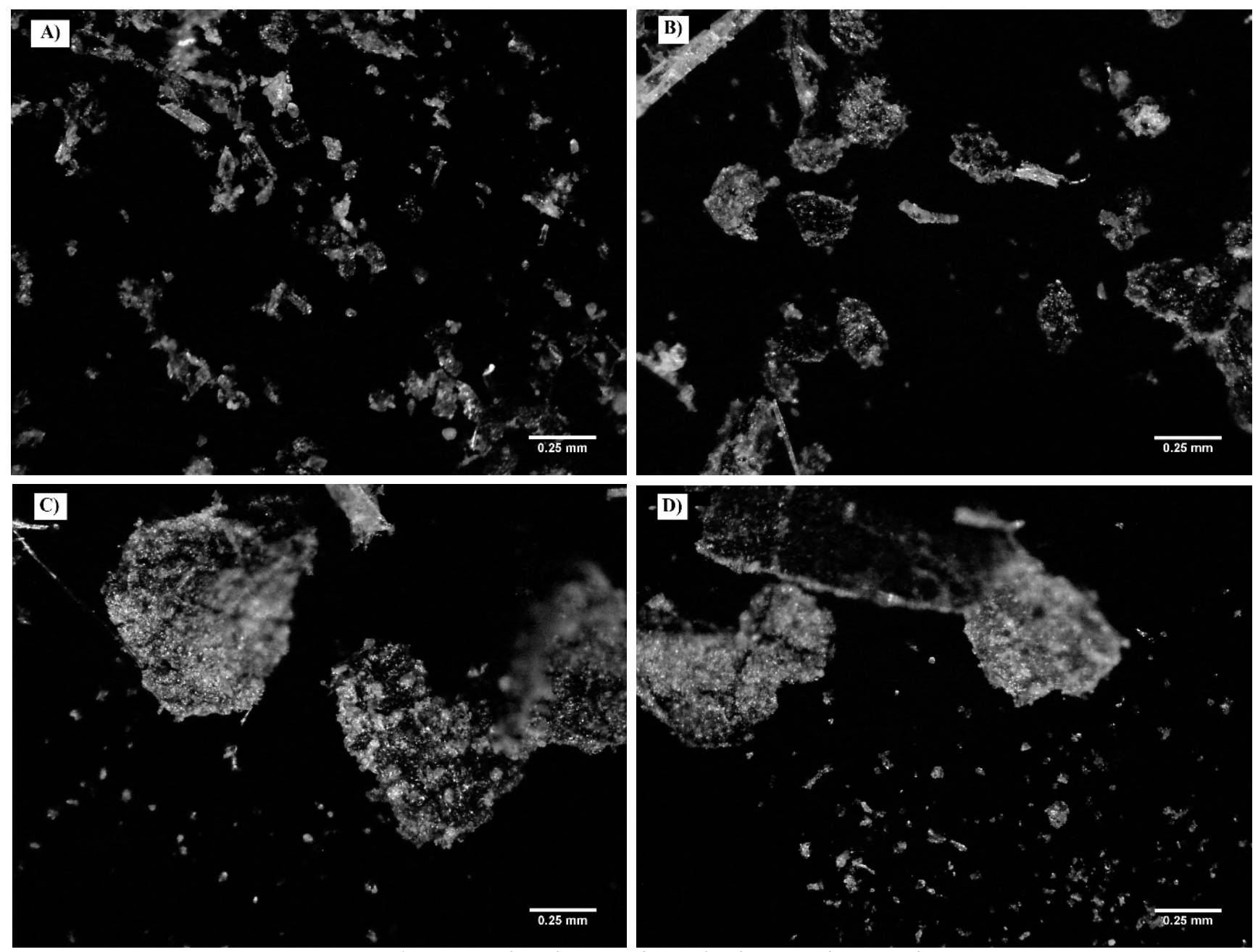

Fig. 4. Images of nettle ground samples for particle sizes of

A) $<100 \mu \mathrm{m}$, B) $100-280 \mu \mathrm{m}$, C) $280-450 \mu \mathrm{m}$ and D) $>450 \mu \mathrm{m}$ obtained by light microscope.

\section{CONCLUSION}

Results obtained by principal component analysis for first derivative of NIR spectra gave better results in terms of separating different medicinal plants of the same particle size at PCA plot since first derivation removes or suppress constant background signals and enhance the visual resolution. For the uniformed particle sizes, NIRS showed excellent differentiation by clustering different medicinal plants. It can be concluded that NIRS method could be used for in line monitoring of the milling process of different medicinal plants regarding the quality control of the final product.

ACKNOWLEDGMENT: This study is a contribution to the project "Application of microreactors in the analysis of antioxidant activity of medicinal plants (MICRO-AA)“, project number HR.3.2.01-0069, which is funded by the European Social Fund (ESF) through the Human Resources Development program.

\section{REFERENCES}

Alcalà, M., Blanco, M., Bautista, M., Gonzàlez, J.M. (2010). On-Line Monitoring of A Granulation Process By NIR Spectroscopy. Journal of Pharmaceutical Sciences, 99 (1), 336345.
Baer, R. J., Frank, J. F., Loewenstein, M., Birth, G. S. (1983). Compositional analysis of whey powder using near infrared diffuse reflectance spectroscopy. Journal of Food Science, 48 (3), 959-961.

Barnes, R.J., Dhanoa, M.S., Lister, S.J. (1989). Standard normal variate transformation and de-trending of near-infrared diffuse reflectance spectra. Appl. Spectrosc., 43, 772-777.

Buckton, G., Yonemochi, E., Hammond, J., \& Moffat, A. (1998). The use of near infra-red spectroscopy to detect changes in the form of amorphous and crystalline lactose. International Journal of Pharmaceutics, 168, 231-241.

Chen, X., Wu, D., He, Y., Liu S. (2011). Nondestructive differentiation of Panax species using visible and shortwave near-infrared spectroscopy. Food and Bioprocess Technology, 4, 753-761.

Ely, D.R., Thommes, M., Carvajal, M.T. (2008). Analysis of the effects of particle size and densification on NIR spectra Colloids and Surfaces. Physicochemical and Engineering Aspects, 331 (1-2), 63-67.

El-Hagrasy, A. S., Morris, H. R., D’Amico, F., Lodder, R. A., Drennen, J. K. (2003). Near-infrared spectroscopy and imaging for the monitoring of powder blend homogeneity. Journal of Pharmaceutical Sciences, 90, 1298-1307.

Hogan, S. E., \& Buckton, G. (2001). The application of near infrared spectroscopy and dynamic vapor sorption to quantify 
low amorphous contents of crystalline lactose. Pharmaceutical Research, 18, 112-116.

Jamrógiewicz, M. (2012). Application of the near-infrared spectroscopy in the pharmaceutical technology. Journal of Pharmaceutical and Biomedical Analysis, 66, 1-10.

Kaffa, K. J., Norris, K. H., Kulscár, F., Draskovits, I. (1982). Attempts to determine fat, protein and carbohydrate content in cocoa powder by the NIR technique. Acta Alimentaria, 11, 271-288.

Lane, R. A., \& Buckton, G. (2000) The novel combination of dynamic vapour sorption gravimetricanalysis and near infrared spectroscopy as a hyphenated technique. International Journal of Pharmaceutics, 207, 49-56.

Laporte, M. F., \& Paquin, P. (1999). Near-infrared analysis of fat, protein, and casein in cow's milk. Journal of Agricultural and Food Chemistry, 47, 2600-2605.

Luner, P. E., Majuru, S., Seyer, J. J., Kemper, M. S. (2000). Quantifying crystalline form composition in binary powder mixtures using near-infrared reflectance spectroscopy. Pharmaceutical Development and Technology, 5, 231-246.

MATHEMATICA (Data Analysis Software System), v. 10.0 (2014). Wolfram Research, USA (www.wolfram.com)

Muzzio, F. J., Robinson, P., Wightman, C., \& Brone, D. (1997). Sampling practices in powder blending. International Journal of Pharmaceutics, 155, 153-178.

Papini, M. (1996). Study of the radiative properties of powdered and fibrous polymers. Vibrational Spectroscopy, 11, 61-68.

Paris, I., Janoly-Dumenil, A., Paci, Mercier, L., Bourget, P., Brion, F., Chaminade, P., Rieutord, A. (2006). Near infrared spectroscopy and process analytical technology to master the process of busulfan paediatric capsules in a university hospital. Journal of Pharmaceutical and Biomedical Analysis, 41, 11711178.

Pasikatan, M.C., Steele, J.L., Spillman, C.K., Haque, E (2001). Near infrared reflectance spectroscopy for online particle size analysis of powders and ground materials. Journal of Near Infrared Spectroscopy, 9, 153-164.

Porfire, A., Rus, L., Vonica, A.L., Tomuta, I. (2012). Highthroughput NIR-chemometric methods for determination of drug content and pharmaceutical properties of indapamide powder blends for tabletting. Journal of Pharmaceutical and Biomedical Analysis, 70, 301-309.

Scotter, C. (1990). Use of near infrared spectroscopy in the food industry with particular reference to its applications to on/inline food processes. Food Control, 1, 142-149.

Siesler, H.W., Ozaki, Y., Kawata, S., Heise, H.M. (2002). Nearinfrared spectroscopy. Principles, instruments, applications, Wiley, Weinheim, USA.

STATISTICA (Data Analysis Software System), v. 10.0 (2010). StatSoft, Inc, USA (www.statsoft.com)

Tarkosova, J., Copikova, J. (2000). Fourier transform near infrared spectroscopy applied to analysis of chocolate. Journal of Near Infrared Spectroscopy, 8, 251-257.

Valinger, D., Benković, M., Gajdoš Kljusurić, J., Bauman, I., Kurtanjek, Ž. (2011) Application of NIR spectroscopy for monitoring different particle sizes of sucrose. Journal on processing and energy in agriculture, 15 (3), 188-190

Wang, L., Lee, F.S.C., Wang, X. (2007). Near-infrared spectroscopy for classification of licorice (Glycyrrhizia uralensis Fisch) and prediction of the glycyrrhizic acid (GA) content. LWT - Food Science and Technology, 40, 83-88.

Wargo, D. J., Drennen, J.K. (1996). Near-infrared spectroscopic characterization of pharmaceutical powder blends. Journal of Pharmaceutical and Biomedical Analysis, 14, 1415-1423.

Woo, Y.A., Kim, H.J., Ze K.R., Chung, H. (2005). Near-infrared (NIR) spectroscopy for the non-destructive and fast determination of geographical origin of Angelicae gigantis Radix. Journal of Pharmaceutical and Biomedical Analysis, 36, 955-959.

Wu, Z.S., Xu, B., Du, M., Sui, C., Shi, X., Qiao Y.J. (2012). Validation of a NIR quantification method for the determination of chlorogenic acid in Lonicera japonica solution in ethanol precipitation process. Journal of Pharmaceutical and Biomedical Analysis, 62, 1-6.

Zhang, Z., Tang, Y. (2005). Identification of rhubarb samples by using NIR spectrometry and Takagi-Sugeno fuzzy system. Spectroscopy Letters, 38, 447-457.

Received: 07. 02. 2017.

Accepted: 14. 3. 2017. 